\title{
PENGARUH ECONOMIC VALUE ADDED (EVA) DAN MARKET VALUE ADDED (MVA) TERHADAP RETURN SAHAM PERUSAHAAN OTOMOTIF DI INDONESIA TAHUN 2007-2010
}

\author{
Putri Kurnia Widiati \\ Fakultas Ekonomik UIN Maulana Malik Ibrahim Malang \\ Jl. Gajayana 50 Malang \\ kurniawidiatiputri@gmail.com
}

Abstract

This study analyzed the effect of Economic Value Added (EVA), Market Value Added (MVA) of otomotif companies Stock return listed on stock exchanges Indonesia, because otomotif companies have an important position on Indonesian Economics.Population of this research are otomotif company that listed on the Stock Exchange of Indonesia from 2007-2010 with sensus sampling method and multiple regresion analysis to analyzed. For the parsial side Market Value Added (MVA) has an influence to stock return of Otomotif Company that listed on the Stock Exchange. To get the trust from investor, otomotif company should have good performance with a good value of Market Value Added, because Market Value Added has significant effect to stock return; and have a good prediction about another factor that influence the stock return wich used histories data for the indicator.

Keywords: economic value added, market value added, return saham

Sektor otomotif memegang peranan penting dalam perekonomian Indonesia. Saat krisis global melanda pada 2008-2009, industri otomotif dan komponennya tumbuh positif di saat beberapa industri manufaktur melambat. Penjualan mobil di Indonesia didominasi oleh mobil-mobil penumpang. Sekitar $75 \%$ penjualan mobil di 
Indonesia merupakan penjualan mobil penumpang dan sisanya merupakan mobilmobil komersial. Penjualan mobil di Indonesia didominasi oleh segmen multi purpose vehicle $(M P V)$. Berdasarkan merek, Toyota merupakan market leader dengan menguasai 37,9\% pasar mobil, diikuti Daihatsu dan Mitsibushi, masing-masing menguasai $14,7 \%$ dan 14,1\% pasar mobil. Di kawasan ASEAN, Indonesia merupakan salah satu pasar otomotif terbesar bersama dengan Thailand dan Malaysia. Tahun 2008, Indonesia menguasai $28 \%$ dari total penjualan mobil di ASEAN, di bawah Thailand yang menguasai 29\%. Namun, pada 2009 pangsa pasar mobil Indonesia di ASEAN sempat turun menjadi 25\% akibat krisis global (Bernando, 2010).

Sektor otomotif telah dijadikan sebagai salah satu primadona industri oleh Departemen Perindustrian. Hal itu terlihat dari target industri otomotif nasional untuk 2011-2025 yang dikeluarkan Deperin. Menurut Deperin, proyeksi pertumbuhan produksi mobil di Indonesia setelah 2010 setiap tahunnya tumbuh $10 \%$. Karena itu pula, diperkirakan pada 2025 akan mencapai 4,17 juta unit. Proyeksi pertumbuhan industri mobil dan sepeda motor di Indonesia sampai 2025 (juta unit).

Minat investor untuk mengembangkan usaha di bidang otomotif di Indonesia, menyebabkan ketertarikan investor dalam menanamkan dananya di pasar modal yang tidak hanya bertujuan dalam jangka pendek tetapi juga bertujuan untuk memperoleh pendapatan dalam jangka panjang. Pendapatan yang diinginkan oleh para pemegang saham adalah pendapatan deviden (dividen yield) dan capital gain. Dividend yield digunakan untuk mengukur jumlah dividen per lembar saham terhadap harga saham dalam bentuk prosentase. Semakin besar dividend yield, maka investor akan semakin tertarik untuk membeli saham tersebut. Di sisi lain semakin tinggi harga pasar menunjukkan bahwa saham tersebut juga semakin diminati oleh investor karena semakin tinggi harga saham akan menghasilkan capital gain yang semakin besar pula. Capital gain merupakan selisih antara harga pasar periode sekarang dengan harga periode sebelumnya. Dividend yield dan capital gain merupakan total return yang akan diterima oleh para investor dalam jangka panjang (Ang, 1997:87).

Untuk melakukan analisis tentang return saham tersebut diperlukan adanya informasi yang bersifat fundamental. Analisis fundamental didasarkan pada informasi-informasi yang diterbitkan oleh emiten maupun administrator bursa efek. Analisis ini dimulai dari siklus perusahaan secara umum, selanjutnya kesektor industrinya, akhirnya dilakukan evaluasi terhadap harga saham yang diterbitkan. Analisis fundamental dipengaruhi oleh rasio-rasio keuangan yang merupakan salah satu indikator kinerja keuangan perusahaan.

Perkembangan ilmu pengetahuan yang demikian pesat dan tuntutan pasar ekonomi dunia mendorong para ahli untuk menemukan dan mengembangkan alat ukur lain yang lebih akurat dalam mengukur kinerja perusahaan. Hal ini juga didorong oleh desakan para investor dan penyedia dana agar mempunyai acuan yang lebih 
dapat dipertanggungjawabkan keakuratannya dalam mengalokasikan dananya Oleh karena itu, Konsultan Stern Steward Management Service di Amerika Serikat tahun 1989 memperkenalkan konsep Economic Value Added (EVA) dan Market Value Added (MVA) sebagai alat ukur kinerja keuangan dan pasar untuk mengatasi kelemahan metode akuntansi tradisional (rasio keuangan) karena menurut Dodd dan Chen (1996) EVA dan MVA telah dipilih sebagai alat ukur kinerja perusahaan dengan keyakinan bahwa EVA dan MVA mengkorelasikan antara kinerja manajemen dengan return saham.

Wiagustini (2010:97) mengungkapkan bahwa pengukuran kinerja keuangan perusahaan jarang menggunakan perhitungan nilai tambah terhadap biaya modal yang ditanamkan. Pengukuran yang hanya menganalisa laporan keuangan berdasarkan analisis rasio memiliki kelemahan utama, yaitu mengabaikan biaya modal, sehingga sulit untuk mengetahui apakah suatu perusahaan telah berhasil menciptakan nilai ataukah tidak. Selanjutnya, EVA merupakan salah satu alat bantu yang digunakan untuk menunjukkan kinerja suatu perusahaan, yang ditunjukkan dengan angkaangka dari laporan keuangan, fokus penilaian yang digunakan untuk mengukur laba ekonomi dalam suatu perusahaan, yang menyatakan bahwa kesejahteraan hanya dapat tercipta jika perusahaan bisa memenuhi semua biaya operasi (operating costs) dan biaya modal (cost of capital). EVA menjadi relevan untuk mengukur kinerja berdasarkan nilai ekonomis yang dihasilkan oleh perusahaan otomotif. Economic Value Added merupakan ukuran nilai tambah ekonomis yang dihasilkan perusahaan otomotif sebagai akibat dari aktivitas atau strategi manajemen Dengan adanya $E V A$, perusahaan otomotif akan memberikan imbalan aktivitas yang menambah nilai keseluruhan suatu perusahaan.

Pendekatan EVA (Economic Value Added) menjelaskan bahwa perusahaan yang efektif dan efisien adalah perusahaan yang mampu menghasilkan return saham sesuai atau melebihi return yang diharapkan oleh pemilik modal. Farhan Malik (2011) menyatakan bahwa EVA (Economic Value Added) tidak mempunyai pengaruh terhadap return Saham hasil ini tidak konsisten dengan penelitian Lehn dan Makhija (1996) yang menyatakan EVA (Economic Value Added) mempunyai hubungan yang lebih dekat dengan return Saham. Sementara hasil penelitian James L. Dodd and Shimin Chen (1996) menemukan EVA (Economic Value Added) mempunyai hubungan dengan return saham.

Sharman Anil (2010) menyatakan konsep EVA telah memperoleh perhatian penting dalam perekonomian, informasi $E V A$ bermanfaat bagi peneltiian dan manajer yang ada keinginan untuk menerapkan EVA. Kinerja keuangan modern selain EVA yang dikaitkan dengan pasar juga diukur dari Market Value Added (MVA) yang merupakan nilai pasar saham dibandingkan dengan nilai bukunya. Ada hubungan antara EVA dan MVA karena harga saham yang merupakan salah satu komponen penting dalam perhitungan MVA, tergantung pada pada kinerja perusahaan di masa mendatang (Husnan dan Pudjiastuti, 2004). 
Market Value Added (MVA) merupakan selisih antara nilai pasar saham dengan modal sendiri yang disetor oleh pemegang saham. Nilai pasar saham adalah perkalian jumlah saham beredar dengan harga saham. Tingginya insvestor yang ingin menanamkan modalnya di sektor otomotif, menyebabkan selisih antara nilai pasar saham dengan modal sendiri yang disetor oleh pemegang saham positif, sehingga saham perusahaan tersebut dinilai oleh investor lebih besar dari pada nilai buku per lembarnya. Hal ini akan meningkatkan minat investor untuk menanamkan sahamnya di perusahaan tersebut.

Hasil penelitian pengaruh MVA terhadap return saham dilakukan oleh Rousana (1997), yang menunjukkan bahwa MVA belum sepenuhnya digunakan oleh investor dalam perdagangan saham di BEJ. Berdasarkan teori, MVA berhubungan positif dengan return saham karena MVA (Market Value Added) adalah ukuran kumulatif kinerja perusahaan yang memperlihatkan penilaian pasar modal pada waktu tertentu dari EVA yang akan datang (Lehn dan Makhija, 1996 dalam Utama,1997) sehingga apabila EVA bernilai positif maka MVA juga bernilai positif. Namun penelitian tersebut menunjukkan hasil yang bertentangan dengan teori. Pendekatan modern EVA dan MVA dapat digunakan oleh perusahaan semen untuk mengukur kinerja keuangan perusahaan (M. Rajesh, 2012).

Berdasarkan uraian di atas maka tujuan penelitian ini adalah menguji pengaruh Economic Value Added (EVA), Market Value Added (MVA), Terhadap Return Saham Perusahaan otomotif Yang Listing Di Bursa Efek Indonesia.

\section{Penelitian Terdahulu}

Dodd dan Chen (1996) penelitian ini menggunakan 566 data dari tahun 19831992 yang telah digunakan oleh Stern Stewart sebelumnya pada tahun 1992. Penelitian ini untuk mengetahui pengaruh rasio-rasio keuangan terhadap return saham. Variabel yang digunakan adalah EVA, ROI, EPS, ROE, dan return saham. Hasil dari penelitian ini adalah $R O I$, $E P S, R O E$, dan $E V A$ mempunyai pengaruh terhadap return saham. Dan yang paling besar pengaruhnya adalah ROI dibandingkan EVA. Jogiyanto Hartono dan Chendrawati (1999), penelitian ini membandingkan variabel $E V A$ dan $R O I$ dengan pengaruhnya terhadap harga saham. Sample yang digunakan adalah saham $L Q 45$ pada tahun 1994-1996. Alat analisis yang digunakan adalah regresi berganda. Hasil yang ditemukan oleh penelitian menunjukkan bahwa ROI da EVA berpengaruh signifikan terhadap return saham. Dan ROI merupakan ukuran yang lebih baik daripada $E V A$.

Garvey dan Milbourn (2000) melakukan penelitian dengan judul EVA versus Earningss: Does It Matter Which Is More Highly Correlated with Return saham. Hasil penelitian menjelaskan bahwa perusahaan-perusahaan yang telah mengadopsi EVA memang memiliki EVA yang berkorelasi lebih tinggi dengan return saham dibandingkan dengan earnings. 
Shubita (2010) melakukan penelitian dengan judul The Relationship Between EVA and Stock Return. Penelitian ini untuk mengetahui hubungan EVA, Net Income, laba dan Cash Flow dengan return saham. Hasil penelitian menjelaskan bahwa EVA, Net Income, laba dan Cash Flow berhubungan terhadap return saham dengan tingkat signifikansi $10 \%$. Sedangkan variabel yang mempengaruhi return saham adalah Laba.

Dimitrios dan Zeljko (2006) melakukan penelitian dengan judul The Introduction of Economic Value Added (EVA) in the Greek Corporate Sector. Penelitian dilakukan pada perusahaan yang terdaftar di SEA periode 1995-2001. Hasil penelitian menunjukkan adanya hubungan yang kuat antara EVA dan earning (EPS) terhadap return saham. Namun yang menunjukkan pengaruh signifikan terhadap return saham adalah variabel earning.

Imam Ghozali dan Irwansyah (2002) meneliti mengenai EVA (Economic Value Added), MVA (Market Value Added) dan ROA (Return on Asset) terhadap Return Saham. Sampel yang diambil tahun 1996-2000 dengan kriteria tertentu sampel yang digunakan sebanyak 20 perusahaan. Hasil penelitian ini menunjukan hanya MVA yang mempunyai pengaruh yang signifikan terhadap return saham sedangkan EVA dan ROA (Return on Asset) tidak mempunyai pengaruh signifikan terhadap return saham.

Penelitian yang dilakukan Taufik (2007) menghasilkan suatu kesimpulan bahwa EVA, ROE dan ROA mempengaruhi stock return sektor perbankan di PT Bursa Efek Jakarta tahun 2002-2005, namun dominasinya tidak terlalu besar. EVA ternyata lebih superior mempengaruhi stock return sektor perbankan dibandingkan dengan $R O E$ dan ROA. Pihak perusahaan perlu mengadopsi konsep EVA mengingat EVA dapat melakukan pembentukan budaya perusahaan, yaitu terbangunnya suatu mindset dikalangan manajer bahwa mereka harus sadar dan peka untuk terus menerus menciptakan nilai bagi perusahaan.

Agus Hardjito (2009) melakukan penelitian yang bertujuan mengetahui pengaruh simultan dan parsial variabel Economic Value Added (EVA), Return on Assets (ROA), Return on Equity (ROE) dan Net Profit Margin (NPM) terhadap return saham perusahaan manufaktur yang terdaftar di BEI periode tahun 2004-2007. Hasil Penelitian menunjukkan bahwa secara EVA tidak memiliki pengaruh signifikan terhadap return saham perusahaan manufaktur.

Dewanto (2005) bertujuan untuk menganalisis secara parsial dan simultan pengaruh economic value added (EVA), market value added (MVA), residual income dan cash flow operation (CFO) terhadap imbal hasil saham. penelitian ini mengambil obyek perusahaan-perusahaan pada sektor pertambangan di Bursa Efek Jakarta. Hasil penelitian menunjukkan bahwa variabel EVA, MVA, residual income dan Cash Flow Operation mempunyai hubungan yang positif dengan imbal hasil saham, namun secara statistik pengaruhnya tidak signifikan. 
Penelitian Biddle, et al. (1997) penelitian ini menguji hubungan economic value added, residual income, earning dan cash flow operation terhadap return saham. Penelitian mengambil obyek perusahaan-perusahaan yang tercantum dalam daftar Stern Steward \& Company. Hasil penelitian menunjukkan bahwa earnings memiliki hubungan terhadap return saham dibandingkan dengan economic value added, residual income dan cash flow operation.

Peneliti Lehn dan Makhija (1997) bertujuan untuk mempelajari hubungan antara lima indikator pengukuran kinerja keuangan dengan return saham. Kelima indikator tersebut adalah economic value added (EVA), market value added (MVA), return on asset (ROA), return on equity (ROE) dan return on sales (ROS). Penelitian mengambil obyek perusahaan-perusahaan publik di Amerika. Hasil penelitian menunjukkan bahwa indikator EVA, MVA berpengaruh signifikan terhadap return saham, namun EVA memiliki pengaruh yang paling dominan.

Penelitian Garvey dan Milbourn (2000) Penelitian ini hanya menggunakan indikator EVA dan earnings dalam kaitannya dengan return saham. Penelitian ini juga membedakan apakah perusahaan telah mengadopsi EVA atau tidak mengadopsi. Hasil penelitian menunjukkan bahwa perusahaan-perusahaan yang telah mengadopsi EVA memang memiliki EVA yang berkorelasi lebih tinggin dengan return saham dibandingkan dengan earnings. Pradhono (2004) bertujuan untuk menganalisis pengaruh EVA, residual income, earnings dan arus kas operasi terhadap return saham, serta untuk mengetahui indikator mana yang mempunyai pengaruh dominan. Peneliti mengambil obyek perusahaan-perusahaan manufaktur yang tergolong dalam industri consumers goods di Bursa Efek Jakarta. Hasil penelitian menunjukkan bahwa variabel arus kas operasi mempunyai pengaruh dominan terhadap return saham. Selain itu, variabel earnings juga mempunyai pengaruh signifikan.

Penelitian Mundaryatiningsih (2006) menganalisis pengaruh kinerja keuangan dengan menggunakan indikator accounting earnings, return on investment (ROI), economic value added (EVA) dan market value added (MVA) terhadap kapitalisasi pasar perusahaan dan return saham. Peneliti mengambil obyek perusahaanperusahaan yang termasuk dalam $L Q 45$ di Bursa Efek Jakarta. Hasil penelitian menunjukkan bahwa EVA mempunyai pengaruh negatif dan signifikan terhadap return saham. Sedangkan $M V A$ mempunyai pengaruh positif dan signifikan terhadap return saham.

Kyriazis dan Anastassis (2007) bertujuan untuk menyelidiki kekuatan penjelasan dari model EVA berkenaan dengan return saham dan firm market value, dibandingkan dengan indikator variabel akuntansi seperti net income dan operating income. Penelitian mengambil obyek perusahaan-perusahaan publik di Yunani. Hasil penelitian menunjukkan bahwa informasi yang dihasilkan net income dan operating income lebih mempunyai nilai relevan dibandingkan dengan EVA. Selain itu, EVA tidak menunjukkan hubungan yang lebih kuat terhadap return saham, sedangkan $M V A$ perusahaan mempunyai hubungan dibandingkan dengan variabel akuntansi lainnya. 
Muhammad Farhan Malik (2011) melakukan penelitian dengan judul Gauging the Value Relevance among the Major Fundamentals: A Study of Food Sector of Pakistan. Penelitian dilakukan pada perusahaan makanan yang terdaftar di bursa efek Pakistan sebanyak 9 perusahaan. Hasil penelitian menjelaskan bahwa Earning Per Share (EPS) tidak berbengaruh signifikan terhadap return saham, namun Market Value Added mempunyai pengaruh signifikan terhadap return saham perusahaan makanan yang terdaftar di Pakistan.

\section{Return Saham}

Return (kembalian) adalah tingkat keuntungan yang dinikmati pemodal atas investasi yang dilakukannya. Dalam hal ini tujuan dari corporate finance adalah memaksimumkan nilai perusahaan. Memaksimumkan nilai perusahaan berarti memaksimumkan kekayaan pemegang saham. Kekayaan pemegang saham sangat dinilai dari return yang diterima pemegang saham atas investasi yang telah dilakukan di dalam perusahaan. Return yang diterima pemegang saham dapat berupa penerimaan deviden tunai ataupun adanya perubahan harga saham pada suatu periode (Ross, et al., 2003).

Return merupakan keuntungan yang diperoleh oleh investor dari investasi return adalah menggambarkan kondisi dari sebuah investasi keuangan apakah dapat menghasilkan keuntungan ayau kerugian (Brigham, 1999:192). Return sangat erat kaitannya dengan investor, berkaitan dengan deviden di periode sebelumnya dan kondisi pasar di akhir periode (Horne, 1998:26). Jones (2000:124) mendefinisikan return sebagai berikut: (1) Yield, yaitu cash flow yang dibayarkan secara periode kepada pemegang saham (dalam bentuk deviden), (2) Capital Gain/loss yaitu selisih antara harga saham pada saat pembelian dengan harga saham pada saat penjualan.

Return dapat berupa return realisasi ataupun return ekspektasi (Jogiyanto, 2003:109). Return realisasi (realized return) merupakan return yang telah terjadi yang dihitung berdasarkan data historis. Return realisasi penting karena digunakan sebagai salah satu pengukur kinerja dari perusahaan serta sebagai dasar penentuan return ekspektasi (expected return) untuk mengukur resiko di masa yang akan datang.

Sedangkan return ekspektasi adalah return yang diharapkan akan diperoleh investor di masa yang akan datang, jadi sifatnya belum terjadi. Perhitungan return ekspektasi dengan model pasar dilakukan dengan dua tahap, yaitu: (1) membentuk model ekspektasi dengan menggunakan data realisasi selama periode estimasi dan (2) menggunakan model ekspektasi ini untuk mengestimasi return ekspektasi di periode jendela. Model ekspektasi dapat dibentuk dengan menggunakan teknik regresi OLS (Ordinary Least Square). Ross (2003:238) return adalah hasil yang diperoleh dari investasi dengan cara menghitung selisih harga saham periode berjalan dengan periode sebelumnya dengan mengabaikan deviden. 


\section{Economic Value Added (EVA)}

Pendekatan yang lebih baru dalam penilaian kinerja adalah dengan menghitung Economic Value Added (EVA) suatu perusahaan. EVA merupakan salah satu ukuran kinerja operasional yang dikembangkan pertama kali oleh G. Bennet Stewart and Joel M. Stren yaitu seorang analis keuangan dari perusahaan Sten Stewart and Company, dan di Indonesia metode ini dikenal dengan nama Nilai Tambah Ekonomi (NITAMI). Economic Value Added merupakan ukuran nilai tambah ekonomis yang dihasilkan perusahaan sebagai akibat dari aktivitas atau strategi manajemen. Economic Value Added menitikberatkan pada efektivitas manajerial tertentu, yang dapat dihitung dengan menggunakan formula sebagai berikut (Brigham, Eugene F. and Joel F. Houston, 2001):

Selanjutnya Brigham and Houston mengatakan bahwa EVA mampu untuk menghitung laba ekonomi yang sebenarnya dari suatu perusahaan pada tahun tertentu dan sangat berbeda jika dibandingkan laba akuntansi. EVA mencerminkan residual income yang tersisa setelah semua biaya modal, termasuk telah dikurangkan dengan modal saham (ekuitas), sedangkan laba akuntansi dihitung tanpa mengurangkan biaya modal. Modal saham/ekuitas memiliki biaya, karena dana yang diberikan oleh pemegang saham dapat saja diinvestasikan di tempat lain yang dapat memberikan pengembalian kepada mereka. Pengembalian yang dapat diperoleh dari tempat lain atas investasi dengan tingkat risiko yang sama mencerminkan biaya dari ekuitas modal.

EVA menyajikan suatu ukuran yang baik mengenai sampai sejauh mana perusahaan telah memberikan tambahan pada nilai pemegang saham. Oleh karenanya, jika manajer berfokus pada $E V A$, hal ini dapat membantu memastikan bahwa mereka telah menjalankan operasi dengan cara yang konsisten dengan tujuan untuk memaksimalkan kekayaan pemegang saham (Brigham and Houston, 2006:69).

EVA menjadi relevan untuk mengukur kinerja berdasarkan nilai ekonomis yang dihasilkan oleh suatu perusahaan. Dengan adanya EVA, maka pemilik perusahaan akan memberikan imbalan aktivitas yang menambah nilai dan membuang fasilitas yang merusak atau mengurangi nilai keseluruhan suatu perusahaan dan membantu manajemen dalam hal menentukan tujuan internal perusahaan untuk implikasi jangka panjang dan bukan jangka pendek saja (Wiagustini N.L Putu, 2010:98).

\section{Market Value Added (MVA)}

MVA (Market Value Added) adalah perbedaan antara nilai pasar saham perusahaan dengan jumlah ekuitas modal investor yang telah diberikan (Bringham Houstan, 2006:68). Hal ini sesuai dengan sasaran utama dari kebanyakan perusahaan, yaitu untuk memaksimalkan kekayaan pemegang saham. Sasaran ini akan menguntungkan pemegang saham dan membantu untuk memastikan bahwa sumber daya yang terbatas telah dialokasikan secara efisien, dan akan memberikan keuntungan 
pada sisi perekonomian. Semakin tinggi $M V A$, maka semakin baik pekerjaan yang telah dilakukan oleh para manajer bagi pemegang saham perusahaan.

$M V A$ merupakan nilai sekarang dari EVA mendatang, yang didiskontokan pada biaya modal perusahaan. $M V A$ adalah analisis untuk mengukur nilai pasar/saham perusahaan, MVA adalah merupakan turunan dari analisa Economic Value Added (Lee, 2009). MVA dapat diambil sebagai indikasi bahwa pasar mengharapkan manajemen untuk menghasilkan $E V A$ positif di masa yang akan datang dan mengukur kesehatan perusahaan (Fatemi, 2003).

Menurut Brigham, Eugene F. and Joel F. Houston $(2006,112)$ MVA merupakan metode yang mengukur seberapa besar nilai tambah yang berhasil diberikan perusahaan kepada para penyandang dana. MVA hanya dapat dihitung atau diaplikasikan pada untuk perusahaan publik atau yang listed di pasar modal. Menurut Warsono (2003:47), MVA didefinisikan sebagai perbedaan antara nilai pasar ekuitas perusahaan dengan nilai ekuitas yang dipasok para investornya Nilai pasar ekuitas pada periode tertentu dihitung dan hasil perkalian antara jumlah saham yang beredar dengan harga saham setiap lembarnya nilai pasar saham biasa sering disebut juga dengan nilai kapitalisasi pasar saham perusahaan modal ekuitas yang dipasok dihitung dari hasil perkalian jumlah saham yang beredar saat tertentu dengan harga pasar saham per lembarnya saat penawaran perdananya jumlah saham yang beredar ini sudah memasukkan unsur penambahan jumlah saham yang beredar sebagai dampak dari emisi saham baru Modal ekuitas yang dipasok ini dapat juga dilihat dari penjumlahan antara nilai pari saham biasa dengan agio sahamnya.

Djawahir Kusnan (2007:30) market value added mencerminkan ekspektasi pemegang saham terhadap perusahaan dalam menciptakan kekayaan di masa mendatang. MVA lebih merupakan metric kekayaan (wealth metric) yang mengukur nilai perusahaan dari waktu ke waktu. Dierks dan Patel dalam Zaky \& Ary (2002:139) menyatakan bahwa MVA merupakan ukuran kumulatif kinerja keuangan yang menunjukkan seberapa besar nilai tambah terhadap modal yang ditanamkan investor selama perusahaan berdiri atau secara jelas MVA merupakan selisih antara nilai pasar ekuitas (market value of equity) dan nilai buku ekuitas (book value of equity).

Brigham, Eugene F. and Joel F. Houston (2001,114) MVA adalah perbedaan antara nilai pasar perusahaan (termasuk ekuitas dan uang) dan modal keseluruhan yang diinvestasikan dalam perusahaan. Nilai pasar adalah nilai perusahaan, yaitu jumlah nilai pasar dari semua tuntutan modal terhadap perusahaan oleh pasar modal pada tanggal tertentu. MVA meningkat hanya jika modal yang diinvestasikan mendapatkan angka pengembalian lebih besar daripada biaya modal. Semakin besar MVA, semakin baik (Young, 2001:27). 


\section{Konsep Penelitian}

Para investor membutuhkan suatu metode pengukuran kinerja keuangan yang sesuai dengan kondisi nyata. Adapun tujuannya adalah untuk mendorong aktivitasaktivitas perusahaan yang cenderung mampu menambah nilai (value added activities) dan manghapuskan aktivitas-aktivitas perusahaan yang justru merusak nilai (non-value added activities). Nilai tambah ekonomis (economic value added/ EVA) sangat relevan, dikarenakan EVA dapat mengukur prestasi manajemen berdasarkan besar kecilnya nilai tambah yang diciptakan selama suatu periode tertentu. EVA juga dapat digunakan sebagai pedoman dalam hal goal setting, capital budgetting, performance assesment dan incentive compensation suatu perusahaan (Utomo, 1999).

Kinerja keuangan modern selain Economic Value Added (EVA) yang dikaitkan dengan pasar juga diukur dari Market Value Added (MVA) yang merupakan nilai pasar saham dibandingkan dengan nilai bukunya. Ada hubungan antara EVA dan $M V A$ karena harga saham yang yang merupakan salah satu komponen penting dalam perhitungan $M V A$, tergantung pada pada kinerja perusahaan di masa mendatang (Husnan dan Pudjiastuti, 2004:75).

Berdasarkan penjelasan di atas, tampak bahwa variabel EVA dan $M V A$, merupakan variabel-variabel yang menarik untuk diteliti pengaruhnya terhadap return saham. Sehingga dapat disampaikan model penelitian digambarkan sebagai berikut:

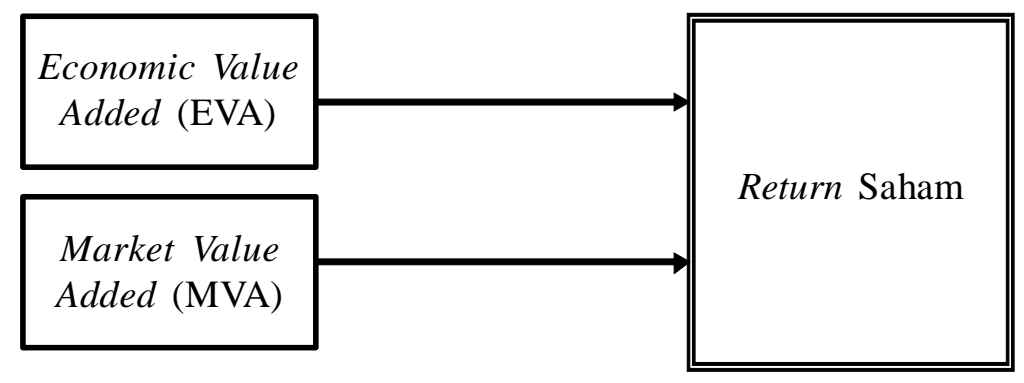

\section{Gambar 1. Kerangka Konseptual Hipotesis Penelitian}

Penelitian pada dasarnya adalah usaha untuk mencari atau mengumpulkan data dan informasi yang akan digunakan untuk menguji suatu hipotesis. Seperti yang dikemukakan oleh Arikunto (2006) bahwa "hipotesis adalah pernyataan yang diterima secara sementara sebagai suatu kebenaran sebagaimana adanya pada saat fenomena dikenal dan merupakan dasar kerja serta panduan Verifikasi. Atau dengan kata lain hipotesis adalah keterangan yang sementara dari hubunganhubungan fenomena yang kompleks."

Sedangkan hipotesis menurut Sugiyono (2002) merupakan jawaban sementara terhadap rumusan masalah penelitian. Sehingga dapat dikatakan bahwa suatu 
hipotesis yang dikemukakan nantinya bukanlah suatu jawaban yang benar secara mutlak, tetapi dipakai sebagai jalan untuk mengatasi permasalahan yang ada, dan masih harus dibuktikan kebenarannya.

Return (kembalian) adalah tingkat keuntungan yang dinikmati pemodal atas investasi yang dilakukannya. Dalam hal ini tujuan dari corporate finance adalah memaksimumkan nilai perusahaan. Memaksimumkan nilai perusahaan berarti memaksimumkan kekayaan pemegang saham. Kekayaan pemegang saham sangat dinilai dari return yang diterima pemegang saham atas investasi yang telah dilakukan di dalam perusahaan (Ross, et al., 2003:105). Bebarapa variabel yang dapat mempengaruhi return perusahaan banyak dilakukan penelitian empirik oleh beberapa peneliti.

Shubita (2010) melakukan penelitian dengan judul The Relationship Between EVA and Stock Return. Hasil penelitian menjelaskan bahwa EVA, Net Income dan Cash Flow mempunyai pengaruh secara simultan terhadap return saham dengan tingkat signifikansi $10 \%$. Sedangkan variabel yang berpengaruh paling dominan terhadap return saham adalah Laba. Hasil penelitian ini didukung oleh Dewanto (2005) dimana penelitian hasil penelitian empirik menyatakan bahwa variabel EVA, MVA, residual income dan Cash Flow Operation mempunyai hubungan yang positif dengan imbal hasil saham dan secara simultan mempunyai pengaruhnya signifikan. Pradono (2004) dengan hasil penelitian empirik menyatakan bahwa variabel EVA, residual income, earning dan arus kas operasi secara simultan mempunyai pengaruh signifikan terhadap return saham.

M. Rajesh, et al. (2012) melakukan penelitian dengan judul "An Empirical Study On EVA and MVA Approach". Hasil penelitian menjelaskan bahwa secara keseluruhan pendekatan modern EVA dan MVA dapat digunakan oleh perusahaan semen untuk mengukur kinerja keuangan (return) perusahaan. Hasil penelitian ini juga didukung oleh penelitian yang dilakukan Makhija (1997), Ghozali (2002), Zeljko (2006), Hardjito (2009) yang menemukan hasil empirik bahwa secara simultan EVA dam MVA mempunyai pengaruh signifikan terhadap return saham.

Berdasarkan hasil kajian empiris maka hipotesis penelitian ini sebagai berikut: Hipotesis 1: Economic Value Added (EVA), Market Value Added (MVA), secara simultan berpengaruh terhadap return saham perusahaan otomotif yang listing di Bursa Efek Indonesia.

EVA merupakan suatu pendekatan dalam pengukuran kinerja untuk mengukur profitabilitas kinerja operasi perusahaan secara nyata, di mana dasarnya $E V A$ adalah laba yang tertinggal setelah dikurangi dengan biaya modal yang diinvestasikan. Hasil penelitian empirik yang dilakukan oleh Dodd dan Shimin (1996) secara parsial EVA mempunyai pengaruh terhadap return saham. Hartono dan Chendrawati (1999), Sjarief, dan Wirjolukito (2004), menghasilkan suatu kesimpulan penelitian bahwa economic value added secara parsial juga mempunyai pengaruh signifikan terhadap return saham. 
Namun hasil penelitian ini bertentangan dengan penelitian yang dilakukan Biddle, et al. (1997) menyatakan bahwa EVA secara parsial tidak mempunyai hubungan dengan return saham, Dewanto (2005), Mundaryatiningsih (2006) menghasilkan kesimpulan bahwa economic value added secara parsial tidak mempunyai pengaruh terhadap return saham.

Market Value Added (MVA) merupakan nilai pasar saham dibandingkan dengan nilai bukunya (Husnan dan Pudjiastuti, 2004). Market Value Added (MVA) merupakan selisih antara nilai pasar saham dengan modal sendiri yang disetor oleh pemegang saham. Ghozali dan Irwansyah (2002) meneliti mengenai EVA (Economic Value Added), MVA (Market Value Added) dan ROA (Return on Asset) terhadap return saham. Hasil penelitian empirik dilakukan oeh Mundaryatiningsih (2006), Lehn dan Makhija (1997) menunjukkan bahwa Market Value Added secara parsial mempunyai hubungan yang positif dan signifikan terhadap return saham. Namun penelitian hasil empirik tersebut bertentangan dengan Dewanto (2005), Agung (2010) dan Hermawan (2008) menunjukkan hasil penelitian bahwa secara parsial tidak adanya hubungan antara MVA terhadap return Saham.

Berdasarkan hasil kajian empiris maka hipotesis penelitian ini sebagai berikut: Hipotesis 2: Economic Value Added (EVA), Market Value Added (MVA), secara parsial berpengaruh terhadap return saham perusahaan otomotif yang listing di Bursa Efek Indonesia.

\section{Definisi Operasional Variabel}

Definisi operasional variabel dalam penelitian ini terdiri dari variabel dependen dan variabel independen sebagai berikut:

\section{Economic Value Added (EVA)}

EVAmengukur nilai tambah (value creation) yang dihasilkan suatu perusahaan dengan cara mengurangi beban biaya modal (cost of capital) yang timbul sebagai akibat investasi yang dilakukan.

Perhitungan EVA menggunakan rumus:

$\mathrm{EVA}=$ NOPAT $-($ WACC $\mathrm{x}$ capital $)$

\section{Market Value Added (MVA)}

Market Value Added (MVA) merupakan selisih antara nilai pasar saham dengan modal sendiri yang disetor oleh pemegang saham. Nilai pasar saham adalah perkalian jumlah saham beredar dengan harga saham. Harga saham didapat dari harga saham rata-rata dalam satu tahun. (Husnan dan Pudjiastuti, 2004). MVA $=($ Jumlah Saham beredar $)($ Harga saham $)-$ Total modal sendiri 


\section{METODE}

\section{Jenis Penelitian}

Sesuai dengan pokok masalah dan tujuan penelitian yang telah dirumuskan, maka jenis penelitian ini adalah explanatory research. Menurut Sugiyono (2006) penelitian menurut tingkat eksplanasi adalah penelitian yang bermaksud menjelaskan kedudukan variabel-variabel yang diteliti, dalam hal ini variabel yang akan diteliti adalah pengaruh antara economic value added (EVA), market value added (MVA) terhadap return saham Perusahaan otomotif di Bursa Efek Indonesia.

\section{Populasi dan Sampel Penelitian}

Populasi yang terkait dengan laporan keuangan dalam penelitian ini adalah seluruh perusahaan yang termasuk di dalam Perusahaan otomotif yang listed di Bursa Efek Indonesia selama selama periode tahun 2007 sampai tahun 2010. Penentuan sampel digunakan dengan metode sensus, di mana sampel yang digunakan adalah perusahaan yang terdaftar pada industri otomotif dan mempublikasikan laporan keuangannya selama periode tahun 2007 sampai dengan tahun 2010.

Berdasarkan kriteria di atas, maka perusahaan otomotif yang dapat dijadikan sampel penelitian sebagai berikut:

\section{Tabel 1. Sampel Penelitian}

\begin{tabular}{lll}
\hline No & Kode & \multicolumn{1}{c}{ Nama Perusahaan } \\
\hline 1 & ASII & PT. Astra Internasional, Tbk \\
2 & AUTO & PT. Astra Otopart, Tbk \\
3 & GJTL & PT. Gadjah Tunggal, Tbk \\
4 & GDYR & PT. Goodyear, Tbk \\
5 & INDS & PT. Indospring, Tbk \\
6 & LPIN & PT. Multi Prima Sejahtera, Tbk \\
7 & MASA & PT. Multistrada Arah Sarana, Tbk \\
8 & NIPS & PT. Nippres, Tbk \\
9 & PRAS & PT. Prima Alloy Stell, Tbk \\
10 & SMSM & PT. Selamat Sempurna, Tbk \\
11 & BRAM & PT. Indokordsa, Tbk \\
12 & IMAS & PT. Indomobil Sukses Makmur, Tbk \\
\hline
\end{tabular}

\section{Jenis dan Sumber Data}

Jenis data yang digunakan dalam penelitian ini adalah data sekunder berupa laporan tahunan atau annual report yang diperoleh dari situs resmi Bursa Efek Indonesia (BEI) pada (http://www.idx.co.id). 


\section{Teknik Pengumpulan Data}

Teknik atau metode yang akan digunakan dalam pengumpulan-pengumpulan data adalah dokumentasi yang merupakan teknik pengumpulan data dari berbagai sumber yang sifatnya tertulis yang menyangkut Economic Value Added (EVA), Market Value Added (MVA) Terhadap Return Saham.

\section{Metode Analisis Data}

Analisis data yang digunakan dalam penelitian menggunakan Analisis regresi berganda yang digunakan untuk mengetahui pengaruh Economic Value Added (EVA), Market Value Added (MVA) Terhadap Return Saham.

\section{Pengujian Asumsi Klasik}

Model pengujian hipotesis berdasarkan analisis regresi yang digunakan dalam penelitian ini harus memenuhi asumsi agar menghasilkan nilai parameter yang benar. Asumsi lain tersebut antara lain tidak terdapat adanya multikolinearitas, heteroskedastisitas, dan autokorelasi.

\section{Multikolinearitas}

Multikolinearitas adalah penunjukan adanya hubungan linear diantara variabel independen. Kondisi ini harus dihindari agar hasil pengujian tidak bias. Pengujian Multikolinearitas dalam penelitian ini menggunakan nilai Varian Inflation Factor (VIF) yang diperoleh dari hasil pengujian hipotesis. Apabila nilai VIF lebih besar dari 10 berarti terjadi masalah yang berkaitan dengan multikolinearitas jika nilai VIF-nya dibawah 10 (Gujarati, 1992).

\section{Heteroskedastisitas}

Heteroskedastisitas adalah varian faktor pengganggu (error) yang terjadi dalam model regresi bersifat tidak sama atau tidak konstan. Oleh karena itu, suatu model regresi harus terhindar dari faktor pengganggu. Heteroskedastisitas dalam penelitian ini menggunakan korelasi spearman. Apabila nilai korelasi Spearman's rho dibawah 0,7 berarti model regresi menunjukkan tidak adanya heteroskedastisitas. Sebaliknya jika nilai rho di atas 0,7 maka model regresi menunjukkan adanya permasalahan Heteroskedastisitas (Gujarati, 1992).

\section{Autokorelasi}

Pengujian autokorelasi akan dilakukan berdasarkan pada nilai Durbin-Westonnya. Pengujian otokorelasi ini bertujuan untuk mengetahui ada tidaknya korelasi 
antar waktu. Model regresi akan bebas dari permasalahan autokorelasi jika memenuhi kriteria sebagai berikut $d_{\text {statistik }}>d_{L}$ atau $<4-d_{L}$

\section{Pengujian Hipotesis}

\section{Pengujian Secara Simultan}

Untuk menguji hipotesis satu (simultan) alat uji yang dipergunakan adalah koefisien korelasi berganda $\mathrm{R}$ dan $\mathrm{R}^{2}$. Koefisien korelasi berganda dan koefisien determinasi berganda merupakan uji yang digunakan untuk mengetahui keeratan pengaruh antara variabel bebas (X) dengan variabel terikat (Y). Mudrajad (2003,98) uji $\mathrm{F}$ pada dasarnya menunjukkan apakah semua variabel bebas yang dimasukkan dalam model mempunyai pengaruh secara bersama-sama terhadap variabel terikat.

Pengujian hipotesis ini digunakan untuk menguji pengaruh secara simultan variabel Economic Value Added (EVA), Market Value Added (MVA) berpengaruh signifikan terhadapr eturn saham perusahaan otomotif. Dengan tingkat signifikansi $\alpha=5 \%$ dan dengan degree of freedom $(\mathrm{k})$ dan (n-k-1) di mana $\mathrm{n}$ adalah jumlah

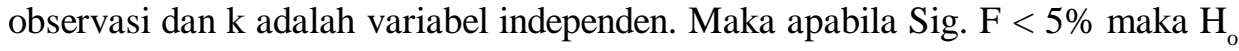
ditolak dan $\mathrm{H}_{\mathrm{a}}$ diterima dan jika Sig. $\mathrm{F}>5 \%$ maka $\mathrm{H}_{\mathrm{o}}$ diterima dan $\mathrm{H}_{\mathrm{a}}$ ditolak

\section{Pengujian Secara Parsial}

Pengujian hipotesisdua (secara parsial) dalam penelitian ini berdasarkan pada analisis nilai t, yang dihasilkan dari model regresi berganda. Dengan tingkat signifikansi $\alpha=5 \%$ dan dengan degree of freedom $(\mathrm{k})$ dan $(\mathrm{n}-\mathrm{k})$ di mana $\mathrm{n}$ adalah jumlah observasi dan $\mathrm{k}$ adalah variabel independen. Maka apabila Sig. $\mathrm{t}<5 \%$ maka $\mathrm{H}_{\mathrm{o}}$ ditolak dan $\mathrm{H}_{\mathrm{a}}$ diterima dan jika Sig. $\mathrm{t}>5 \%$ maka $\mathrm{H}_{\mathrm{o}}$ diterima dan $\mathrm{H}_{\mathrm{a}}$ ditolak.

\section{HASIL DAN PEMBAHASAN}

\section{Hasil Confirmatory Factor Analysis}

Hasil perhitungan analisis regresi linier berganda dilakukan dengan bantuan Statistical Package for Social Science (SPSS) 15.0 for windows, seperti yang ditampilkan pada Tabel 2 berikut: 
Tabel 2. Rekapitulasi Hasil Analisis Regresi Linier Berganda terhadap Return Saham Automotif di Indonesia

\begin{tabular}{lcccl}
\hline Variabel & B & t & Sig t & \multicolumn{1}{c}{ Ket } \\
\hline EVA & 0.074 & 0.690 & 0.494 & Tidk Sig \\
$M V A$ & 0.281 & 2.606 & 0.013 & Sig \\
\hline & & & & \\
$\alpha$ & $: 5 \%$ & & & \\
R & $: 0,718$ & & & \\
$R$ Square & $: 0,516$ & & & \\
Nilai F & $: 8,947$ & & & \\
Sig & $: 0,000$ & & & \\
\hline
\end{tabular}

Sumber: Data Sekunder Diolah, tahun 2012

Dengan memperhatikan nilai-nilai data tabel di atas maka dapat disusun suatu persamaan regresi linier berganda sebagai berikut:

$\mathrm{Y}=0,074 \mathrm{EVA}+0,281 \mathrm{MVA}$

Berdasarkan persamaan di atas maka maknanya dapat diuraikan sebagai berikut:

- $\quad$ Besarnya koefisien untuk variabel Ecomic Value Added (EVA) sebesar 0,074 dengan arah koefisien positif. Hal ini mempunyai makna bahwa apabila nilai EVA yang menggambarkan nilai tambah (value creation) yang dihasilkan suatu perusahaan otomotif mengalami peningkatan maka return saham akan meningkat sebesar 0,074 .

- $\quad$ Besarnya koefisien untuk variabel Market value Added (MVA) sebesar 0,280 dengan arah koefisien positif. Hal ini mempunyai makna bahwa apabila nilai pasar saham perusahaan otomotif mengalami peningkatan maka return saham akan meningkat sebesar 0,280.

- $\quad$ Besarnya nilai koefisien korelasi berganda (R) sebesar 0,718 atau 71,8\% hal ini menunjukan bahwa Economic Value Added (EVA), Market Value Added (MVA) memiliki hubungan dengan return saham sebesar $71,8 \%$.

- $\quad$ Daya prediksi dari model regresi ( $R$-square) yang dibentuk dalam pengujian ini sebesar 0,516 atau 51,6\%. Hal ini menunjukan bahwa besarnya pengaruh Economic Value Added (EVA), Market Value Added (MVA terhadap return saham perusahaan otomotif yang terdaftar di Bursa Efek Indonesia sebesar $51,6 \%$, sedangkan sisanya sebesar 48,4\% dipengaruhi variabel-variabel lain yang belum dimasukkan dalam penelitian.

\section{Pengujian Hipotesis Pertama}

Pengujian hipotesis satu menggunakan uji F-statistik, yaitu digunakan untuk menguji pengaruh secara simultan Economic Value Added (EVA), Market Value 
Added (MVA), tidak berpengaruh signifikan terhadap return saham perusahaan otomotif yang terdaftar di Bursa Efek Indonesia. Dasar pengambilan keputusannya adalah melakukan analisis dengan program SPSS. Dengan program SPSS, uji Anova atau $\mathrm{F}$ test, bila didapatkan koefisien signifikan $\mathrm{F}(\beta \mathrm{i})<$ taraf signifikansi yang telah ditetapkan $(\alpha=5 \%)$, maka model regresi bisa dipakai untuk memprediksi variabel dependen (Imam Ghozali, 2001).

Dalam pengujian hipotesis satu ini akan diuji dengan uji $\mathrm{F}$ yang dihasilkan dari model regresi linier berganda. Seperti tampak pada tabel 2, diperoleh $\mathrm{F}_{\text {hitung }}$ sebesar 8.947 dengan tingkat signifikansi $F$ sebesar 0,000. Tingkat signifikansi sebesar 0.000 tersebut lebih kecil dari nilai alpha $(\alpha)$ dalam penelitian ini adalah sebesar $5 \%$ (0,05). Hal ini dapat disimpulkan bahwa secara simultan variabel Economic Value Added (EVA), Market Value Added (MVA) berpengaruh signifikan terhadap return saham perusahaan otomotif yang terdaftar di Bursa Efek Indonesia.

\section{Pengujian Hipotesis Hipotesis Dua}

Pengujian hipotesis dua dalam penelitian ini bertujuan untuk menginvestigasi adanya pengaruh secara parsial variabel Economic Value Added (EVA), Market Value Added (MVA) terhadap return saham perusahaanotomotif yang terdaftar di Bursa Efek Indonesia. Uji Parsial (Uji t Statistik) digunakan untuk mengetahui pengaruh masing-masing variabel independen terhadap variabel dependen (Imam Ghozali, 2006). Dalam pengujian hipotesis kedua diuji dengan uji t yang dihasilkan dari model regresi linier berganda.

Besarnya probabilitas untuk variabel Economic Value Added EVA $\left(\mathrm{X}_{1}\right)$ sebesar 0,494 lebih besar dari signifikan statistik pada $\alpha=5 \%(0,05)$, sehingga mempunyai arti bahwa $\beta_{1}$ tidak signifikan. Hal ini mempunyai arti bahwa Economic Value Added (EVA) tidak mempunyai pengaruh signifikan terhadap return saham perusahaan otomotif yang terdaftar di Bursa Efek Indonesia.

Besarnya nilai probabilitas untuk variabel Market Value Added/MVA $\left(\mathrm{X}_{2}\right)$ sebesar 0,013 lebih kecil dari signifikan statistik pada $\alpha=5 \%(0,05)$, sehingga mempunyai arti bahwa $\beta_{2}$ signifikan. Hal ini mempunyai arti bahwa Market Value Added (MVA) berpengaruh signifikan terhadap return saham perusahaan otomotif yang terdaftar di Bursa Efek Indonesia.

\section{Pembahasan}

Berdasarkan hasil analisa dan uji hipotesis dalam penelitian dinyatakan bahwa terdapat pengaruh secara simultan Economic Value Added (EVA), Market Value Added (MVA) terhadap return saham perusahaan otomotif yang terdaftar di Bursa Efek Indonesia. Economic Value Added (EVA) sebagai nilai tambah ekonomis yang diciptakan perusahaan dari kegiatan selama periode tertentu. Market Value 
Added (MVA) yang dapat digunakan untuk menganalisis atau mengukur nilai pasar atau saham perusahaan.

Hasil penelitian ini mendukung penelitian yang dilakukan oleh Juliati Syarief dan Aruna W (2004) menyatakan bahwa EVA dan DER secara simultan berpengaruh signifikan terhadap perubahan harga saham. Dimitrios dan Zeljko (2006) EVA dan earning per share secara simultan berpengaruh terhadap return saham perusahaan di Greek Corporate Sector. Dewanto (2005) dan Biddle (1997) menyatakan bahwa EVA, MVA, residual income dan Cash Flow mempunyai hubungan positif dan signifikan terhadap return saham.

Penelitian yang dilakukan oleh Shubita (2010) menyatakan bahwa EVA, net income (laba) dan cash flow secara simultan mempunyai pengaruh signifikan terhadap return perusahaan di pasar modal Jordania. Sedangkan M. Rajesh (2012) juga menyatakan bahwa Economic Value Added (EVA) dan Market Value Added (MVA) mempunyai pengaruh signifikan terhadap kinerja keuangan perusahaan semen di pasar modal India.

Hasil penelitian di atas menjelaskan bahwa variabel Economic Value Added (EVA), Market Value Added (MVA) dapat digunakan perusahaan untuk mengukur tingkat kinerja perusahaan. Hal ini dikarenakan MVA merupakan pendekatan baru yang banyak digunakan untuk menilai kinerja keuangan perusahaan, walaupun belum popule rdikalangan investror. Penilaian Economic Value Added (EVA) digunakan untuk melihat nilai tambah internal yang dimiliki perusahaan, sedangkan penilaian Market Value Added (MVA) digunakan untuk melihat nilai tambah eksternal atau nilai tambah pasar yang diberikan oleh perusahaan.

Hasil pengujian hipotesis secara parsial menyatakan bahwa Economic Value Added (EVA) tidak mempunyai pengaruh signifikan terhadap return saham perusahaan otomotif yang terdaftar di Bursa Efek Indonesia. Dari hasil pengamatan yang dilakukan pada data perusahaan sebanyak 12 sampel pengamatan pada perusahaan otomotif yang terdaftar di Bursa Efek Indonesia, terlihat bahwa pada variabel EVA dengan periode pengamatan tahun 2007-2010 hasil perhitungan EVA banyak yang memiliki nilai negatif. Bila disesuaikan dengan teori, bahwa semakin tinggi nilai laba perusahaan akan semakin tinggi pula nilai return saham yang bisa diterima oleh pemegang saham, namun dari pengamatan terlihat bahwa nilai EVA negatif jauh lebih banyak dibandingkan dengan $E V A$ positif, maka akan berdampak negatif terhadap return saham, hal ini terlihat pada hasil uji statistik pada penelitian ini, yang mengatakan EVA tidak mempunyai pengaruh terhadap return saham. Nilai EVA negatif dikarenakan nilai laba operasi sesudah pajak lebih kecil dibandingkan dengan biaya rata-rata tertimbang (WACC) dan besarnya modal itu sendiri. Keadaan ini terjadi dikarenakan adanya kemungkinan seluruh sumber pembiayaan (yang berasal dari capital terdiri dari Long Term Liabilities dan Equitas) yang digunakan oleh perusahaan untuk menghasilkan profit dan digunakan untuk investasi menurun. 
Hasil penelitian ini mendukung penelitian yang dilakukan oleh Pradono (2004), Biddle, et al. (1997), Dewanto (2005), Mundaryatiningsih (2006) menghasilkan kesimpulan bahwa economic value added tidak mempunyai pengaruh terhadap return saham. Namun hasil penelitian ini bertentangan dengan penelitian yang dilakukan oleh L. Dodd dan Shimin Chen (1996), Hartono dan Chendrawati (1999), Sjarief, dan Wirjolukito (2004) menghasilkan suatu kesimpulan penelitian bahwa economic value added mempunyai pengaruh signifikan terhadap return saham.

Market Value Added (MVA) merupakan nilai sekarang dari EVA mendatang, yang didiskontokan pada biaya modal perusahaan. $M V A$ adalah alat analisis yang dapat digunakan untuk mengukur nilai pasar atau saham perusahaan. MVA dapat dijadikan dasar bagi manajemen untuk melihat nilai (value) pasar perusahaan di masa datang dan kinerja perusahaan (Khan, 2010). Hasil pengujian hipotesis secara parsial menyatakan bahwa Market Value Added (MVA) mempunyai pengaruh signifikan terhadap return saham perusahaan otomotif yang terdaftar di Bursa Efek Indonesia.

Hasil penelitian menunjukkan bahwa Market Value Added (MVA) mempunyai pengaruh signfiikan terhadap return saham perusahaan otomotif yang terdaftar di Bursa Efek Indonesia. Kondisi ini dapat di artikan bahwa perusahaan otomotif di Indonesia memiliki kinerja saham yang lebih baik dan aktif transaksinya di bursa saham, sehingga adanya rata-rata kenaikan harga saham yang ditawarkan pada perusahaan selain itu jumlah saham yang beredar pada perusahaan otomotif juga cenderung lebih banyak. Pada akhirnya dapat dikatakan bahwa apabila dilihat dari variabel Market Value Added (MVA) kinerja perusahaan automotif cenderung lebih baik selama tahun pengamatan penelitian.

Hasil penelitian ini mendukung penelitian yang dilakukan Imam Ghozali dan Irwansyah (2002) Mundaryatiningsih (2006), Lehn dan Makhija (1997) menunjukkan bahwa Market Value Added mempunyai hubungan yang positif dan signifikan terhadap return saham. Pendapat di atas bertentangan dengan beberapa peneliti Dewanto (2005), Agung (2010) dan Hermawan (2008) menunjukkan hasil penelitian bahwa tidak adanya pengaruh Market Value Added terhadap return Saham.

\section{Keterbatasan Penelitian}

Meskipun penelitian ini telah dibuat dengan sebaik-baiknya, namun masih terdapat beberapa keterbatasan, antara lain variabel yang digunakan tidak menggunakan variabel makro (seperti: inflasi, tingkat suku bunga dan lainnya), keterbatasan pada pengambilan variabel yang digunakan dalam penelitian ini, dimana indikator yang digunakan dalam memprediksi return saham adalah faktor-faktor fundamental yang menggunakan data akuntansi bersifat historis, dan besarnya pengaruh Economic Value Added (EVA), Market Value Added (MVA) terhadap return saham perusahaan otomotif yang terdaftar di Bursa Efek Indonesia hanya sebesar 52,1\%, 
sedangkan sisanya sebesar 47,9\% dipengaruhi variabel-variabel lain yang belum dimasukkan dalam penelitian.

\section{Implikasi Penelitian}

Hasil penelitian ini mempemperkuat teori dan hasil penelitian terdahulu tentang pengaruh Economic Value Added, Market Value Added (MVA) terhadap return saham. Kinerja sebuah perusahaan lebih banyak diukur berdasarkan rasio-rasio keuangan selama satu periode tertentu. Pengukuran berdasarkan rasio keuangan ini sangatlah bergantung pada metode atau perlakuan akuntansi yang digunakan dalam menyusun laporan keuangan perusahaan. Sehingga seringkali kinerja perusahaan terlihat baik dan meningkat, yang mana sebenarnya kinerja tidak mengalami peningkatan dan bahkan menurun.

Diperlukannya suatu alat ukur kinerja yang menunjukkan prestasi manajemen sebenarnya dengan tujuan untuk mendorong aktivitas atau strategi yang menambah nilai ekonomis (value added activities) dan menghapuskan aktivitas yang merusak nilai (non-value added activities). Economic Value Added (EVA) sangat relevan dalam hal ini karena EVAdapat mengukur kinerja (prestasi) manajemen berdasarkan besar kecilnya nilai tambah yang diciptakan selama periode tertentu. Selain itu MVAjuga berperan untuk mengetahui kinerja perusahaan yang berhubungan dengan tujuan utama perusahaan dalam memaksimumkan kemakmuran pemegang saham. Kekayaan atau kesejahteraan pemilik (shareholders) akan bertambah atau maksimum jika Market Value Added (MVA) juga bertambah atau maksimum. Hal ini dikarenakan perusahaan otomotif belum menerapkan secara maksimal beberapa strategi dengan menggunakan EVA sebagai alat yang dapat meningkatkan kinerja keuangan perusahaan otomotif.

Tidak selamanya perusahaan yang mempunyai nilai Net Operating Profit after Tax (NOPAT) yang tinggi pasti akan mendapatkan nilai EVA yang tinggi. Banyak perusahaan yang nilai NOPAT-nya paling tinggi dibandingkan dengan perusahaan lain, namun nilai $E V A$-nya kecil bahkan negatif. Keadaan ini menggambarkan bahwa masih banyak perusahaan otomotif yang belum mengunakan biaya modal yang efisien atau kebijakan pengunaan struktur modalnya belum optimal.

Beberapa strategi yang dapat dilakukan perusahaan otomotif untuk meningkatkan economic value added antara lain pertama, perusahaan otomotif yang listing di BEI harus dapat menciptakan nilai (value creation) perusahaan melebihi perusahaan lain atau perusahaan sektor lain, sehingga akan menarik investor dalam menanamkan modalnya. Apalagi dunia otomotif semakin lama banyak mengalami kemajuan, hal ini dapat terlihat dengan munculnya inovasi-inovasi baru untuk menarik dan memenuhi kebutuhan konsumen. Kedua, perusahaan otomotif juga harus lebih memperhatikan struktur modal yang dimiliki, hal ini dikarenakan struktur modal merupakan masalah penting dalam pengambilan keputusan mengenai pembelanjaan 
perusahaan otomotif. Kebijakan struktur modal merupakan faktor fundamental keberhasilan suatu perusahaan (Brigham dan Houston, 2006:98). Kebijakan tersebut merupakan kebijakan yang penting didalam menjalankan aktivitas operasi, mempertahankan, dan mengembangkan perusahaan otomotif. Ketiga, perusahaan otomotif harus mampu mempertahankan fluktuasi harga saham yang stabil, hal ini dikarenakan harga saham sebagai salah satu komponen $M V A$ akan lebih banyak ditentukan oleh kinerja masa depan dan bukan kinerja masa lalunya. Keempat, perusahaan otomotif untuk tetap memiliki hubungan (relasi) yang baik, menciptakan nilai (value) perusahaan yang baik di mata investor sehingga akan timbul suatu kepercayaan investor terhadap perusahaan otomotif dalam menanamkan modalnya. Selain itu perusahaan otomotif harus dapat melihat pasar yang terkait dengan bisnisnya, seperti: usaha penyewaan kendaraan, jasa transportasi umum dan lain sebagainya. Hal-hal lain yang harus diperhatikan oleh industri otomotif adalah jenis produk yang dikeluarkan dan kemudahan masuk keluar pasar.

\section{KESIMPULAN DAN SARAN}

\section{Kesimpulan}

Kesimpulan dalam penelitian ini terdiri dari Economic Value Added (EVA), Market Value Added (MVA) secara simultan mempunyai pengaruh terhadap return saham perusahaan otomotif yang terdaftar di Bursa Efek Indonesia dan Market Value Added (MVA) mempunyai pengaruh terhadap return saham perusahaan otomotif yang terdaftar di Bursa Efek Indonesia. Sedangkan variabel Economic Value Added (EVA) tidak mempunyai pengaruh terhadap return saham perusahaan otomotif yang terdaftar di Bursa Efek Indonesia.

\section{Saran}

Bagi emiten, peningkatan return saham dapat meningkatkan kepercayaan publik investor) terhadap emiten. Kondisi ini sangat penting bagi emiten memerlukan sumber pendanaan baru maka para investor akan merespon positif dan segera menanamkan modalnya. Adapun salah satu upaya yang perlu dilakukan adalah dengan cara menunjukkan kinerja yang baik agar dapat menghasilkan earning dan Market Value Added yang tinggi. Sebagaimana diketahui dari hasil penelitian bahwa market value added adalah variabel yang mempunyai pengaruh signifikan terhadap return saham. Jika hanya MVA yang menjadi dasar untuk memprediks return saham, maka sebaiknya perlu dicermati secara hati-hati. Karena ada banyak faktor (misalnya: faktor makro) yang dapat mempengaruhi return saham bahkan lebih dominan dari indikator kinerja yang banyak didasarkan atas data historis.

Bagi investor, dalam menganalisis kinerja keuangan emiten, informasi mengenai $E V A, M V A$ layak untuk dicermati. Hal ini mengingat bahwa kelima indikator kinerja 
tersebut secara bersama-sama mempengaruhi return saham. Jika terjadi kenaikan $E V A$, kemungkinan dapat terjadi meningkatnya harga per lembar saham ataupun perubahan variabel lain pada periode tersebut. Oleh karena itu investor sebaiknya selalu mengikuti perkembangan harga saham sebelum dan sesudah publikasi laporan keuangan, sehingga investor dapat mengukur return saham secara tepat sebelum mengambil keputusan untuk membeli ataupun menjualnya.

Bagi para akademisi yang berminat untuk melakukan penelitian lebih lanjut mengenai return saham disarankan untuk mengembangkan faktor-faktor lain yang mungkin lebih dominan dalam mempengaruhi return saham, seperti nilai tukar rupiah terhadap mata uang asing, karena faktor fundamental dapat mempengaruhi nilai return saham perusahaan otomotif yang terdaftar di Bursa efek Indonesia; lebih mengembangkan sampel penelitian yang digunakan bukan hanya perusahaan otomotif, namun menggunakan jenis perusahaan lain yang terdaftar di Bursa Efek Indonesia.

\section{DAFTAR PUSTAKA}

Agus, H. 2006. Analisis Pengaruh Kinerja Keuangan dan Return Saham di Bursa Efek Indonesia. Fenomena. Volume 7. No.1.

Agung, T.S. 2010. Analysis of Influence Economic Value Added (EVA) and Market Value Added ( MVA ) Return to Share in Manufacturing Company in Indonesia Stock Exchange. Jurnal Ekonomi dan Bisnis. Vol 6, 38-48.

Ang, R. 1997. Buku Pintar Pasar Modal Indonesia. Jakarta: Mediasoft Indonesia.

Biddle, G.C., R.M. Bowen, and J.S. Wallace. 1997. ’Does EVA Beat Earningss? Evidence on Associations with Return saham sahams and Firm Value. Journal of Accounting and Economics. 24, p 301-336.

Dewanto, H. 2005. Analisis Pengaruh Economic Value Added, Market Value Added, Residual Income dan Cash Flow Operation terhadap Imbal Hasil Saham Sektor Pertambangan di BEJ 1995-2004.TESIS. Universitas Indonesia.

Dimitrios, Z. 2006. The Introduction of Economic Value Added (EVA) in the Greek Corporate Sector. The Southeuropean Review of Business \& Accounting, Volume 4, Number 2, December 2006: ISSN: 1109-6926.

Djawahir, Kusnan, M. 2003. Sulitnya Menciptakan Nilai Tambah bagi Shareholders. Swasembada No.21 Tahun XIX halaman 30-39.

Dodd, James, L., and Shimin, C. 1996. A New Panacea. B and E Review, Jully-September. pp.26-28.

Fabozzi, Frank, J., and Franco, M. 2003. Capital Market Institution and Instruments, 3rd Edition. Prentice Hall, New Jersey: Upper Saddle River.

Fatemi, A., Desai, Anand, S., Katz, Jeffery, P. 2003. Wealth Creation and Managerial Pay: MVA and EVA as Determinant of Executive Compensation. Global Finance Journal No14, pp 159-179.

Garrison, et al. 2007. Managerial Accounting. Edisi 11. Jakarta: Penerbit Salemba Empat. 
Garvey, Gerald, T., and Todd, T.M. 2000. EVA versus Earningss: Does It Matter Which Is More Highly Correlated with Return saham sahams? Journal of Accounting Research Vol. 38, p 209-245.

Ghozali, I., dan Irwansyah. 2002. Analisis Pengaruh Kinerja Keuangan Perusahaan dengan Alat Ukur EVA, MVA dan ROA terhadap Return Saham pada Perusahaan Manufaktur di BEJ. Jurnal Penelitian Akuntansi-Bisnis dan Manajemen, Vol.9, No. 1, April.

Gujarati, Damodar, N. 1995. Basic Econometrics, Third Edition. Singapore: McGraw-Hill Book Co.

Harahap, S.S. 2010. Analisis Kritis atas Laporan Keuangan, Edisi 1. Jakarta: Rajawali Pers. Harjito, D.A., dan Rangga, A. 2009. Analisis Pengaruh Kinerja Keuangan dan Return Saham di Bursa Efek Indonesia. Fenomena, Vol. 7, No.1.

Hartono, J., dan Chendrawati. 1999. ROA, and EVA: A Comparative Empirical Study, Gajah Mada Internasional Journal of Business, Vol. I, No. I, May 1999.

Husnan, S., dan Enny, P. 2004. Dasar-dasar Manajemen Keuangan. UPP. AMP. YKPN.

Imam, G. 2001. Aplikasi Analisis Multivariate Dengan Program SPSS. Semarang: Badan Penerbit Universitas Diponegoro.

Ismaya, S. 2005. Kamus Akuntansi. Bandung: Penerbit Pustaka Grafika.

Kartini, H.G. 2008. Economic Value Added dan Market Value Added terhadap Return Saham. Jurnal Keuangan dan Perbankan Vol 12, No 3, 355-368.

Kusnan, M.D. 2007, Mengukur Kekayaan Perusahaan Swa, 26/XXIlVl68, Desember, hal 30.

Lawrence, K., Sana, M. 2010. Capital return, Cost and EVA for Canadian Firm. North American Journal of Economics and Finance 21 (2010) 256-273.

Lee, S., Kim, W.G. 2009. EVA, Refined EVA, MVA, or Traditional Performance Measures for Hospitality Industry? International Journal of Hospitality Management No 28, pp 439,445

Lehn, K., and Makhija, A. 1997. Accounting Profits and CEO Turnover; An Empirical Examination, 1985-1994. Journal of Applied Corporate Finance, Vol. 10 (2), pp 9097.

Linawati, L. 1999. Economic Value Added sebagai ukuran Keberhasilan Kinerja Manajemen Perusahaan. Jurnal Akuntansi dan Keuangan, Vol. 1, No. 1, Mei 1999.

Malik, M.F. 2011. Gauging the Value Relevance among the Major Fundamentals: A Study of Food Sector of Pakistan. International Research Journal of Finance and Economics. ISSN 1450-2887 Issue 72 (2011).

Melani, K.H. 2007. Para Pencetak Kekayaan di Pasar Modal, Swa, 26/XX111/6-17 Desember, hal 44.

Mudrajad, K. 2003. Metode Riset untuk Bisnis dan Ekonomi. Jakarta: Gramedia Pustaka.

Munawir, S. 2002. Analisis Laporan Keuangan. Yogyakarta: Liberty.

Mundaryatiningsih, S. 2006. Analisis Pengaruh Kinerja Keuangan Perusahaan terhadap Kapitalisasi Pasar dan Return Saham Perusahaan Publik di Bursa Efek Jakarta. TESIS. Institut Teknologi Bandung.

M. Rajesh, Ramana, R., Narayana. 2012. An Empirical Study On EVA and MVAApproach. International Journal Of Marketing, Financial Service, \& Management Research. Vol 1 No. 3 March 2012. 
Natarsyah, S. 2000. Analisis Pengaruh Beberapa Faktor Fundamental dan Risiko Sistematik Terhadap Harga Saham: Kasus Industri barang konsumsi yang go publik di pasar Modal Indonesia, Jurnal Ekonomi Bisnis Indonesia, Vol. 15, no.3, 294-312.

Paulo, F., Luiz, Belfiore, Patricia. 2011. Cash Flow, Earnings Ratio and Stock Return in Emerging Global Regions : Evidence from Lungitudinal Data. Global Economy and Finance Journal, Vol. 4. No 1 March $20110032-43$.

Pradhono, J.C., Yulius. 2005. Pengaruh Economic Value Added, Residual Income, Earnings dan Arus Kas Operasi terhadap Return yang Diterima oleh Pemegang Saham. Jurnal Akuntansi dan Keuangan Vol 6, No 2.

Rousana, M.1997. Memanfaatkan EVA untuk Menilai Perusahaan di Pasar Modal Indonesia, Majalah Usahawan No.4TH XXX (April ):18-20.

Ross, Stephen, A., Randolph, W. Westerfield, and Jeffrey, J. 2002. Corporate Finance, $6^{\text {th }}$ Edition. New York: McGraw-Hill.

Sharman, A.K., and Satish, K. 2010. Economic Value Added (EVA) - Literature Review and Relevant Issues. International Journal of Economics and Finance. Vol. 2, No. 2; May 2010.

Shubita, M.F. 2010. The Relationship Between EVA and Stock Return. International Research Journal of Finance and Economics, ISSN 1450-2887 Issue 59.

Subalno. 2009. Analisis Pengaruh Faktor Fundamental dan Kondisi Ekonomi Terhadap Return Saham (Study Kasus Pada Perusahaan Otomotif dan Komponen Yang Listed di Bursa Efek Indonesia Periode 2003-2007), TESIS. Universitas Diponegoro. Semarang.

Taufik. 2007. Pengaruh Pendekatan Traditional Accounting dan Economic Value Added terhadap Stock Return Perusahaan Sektor Perbankan di PT Bursa Efek Jakarta. Jurnal Manajemen \& Bisnis Sriwijaya Vol 5, No 10.

Utama, S. 1997. EVA Pengukur Penciptaan Nilai Perusahaan. Manajemen Usahawan Indonesia, No 4Th. XVI April, 1997.

Warsono. 2003. Manajemen Keuangan Perusahan. Edisi Ketiga Jilid 1. Jakarta: Bayumedia.

Wiagustini, N.L.P. 2010. Dasar-Dasar Manajemen Keuangan. Denpasar: Udayana University Press.

Wild, et al. 2005. Financial Statement Analysis. Jakarta: Penerbit Salemba Empat.

Yogo, P. 1998. Keterkaitan Kinerja Keuangan dan Harga Saham. Usahawan. No. 12. Jakarta: BPFE UI.

Young, S.D., and Stephen, F. O'Byrne. 2001. EVA and Value-Based Management: A Practical Guide to Implementation. NewYork: Mc Graw-Hill.

Zaki, B., dan Ary, L. 2002. Asosiasi Economic Value Added (EVA), Market Value Added (MVA) dan Rasio Profitabilitas terhadap Harga Saham. TEMA. Vol. III, No.2, September, hal 133-149. 